Review

\title{
Biomass Gasification and Liquid Fuel (BTL) Synthesis Using an Entrained-flow Type Gasifier in Japan
}

\author{
Tomoko OGI and Masakazu NAKANISHI \\ (Received November 18, 2014)
}

\begin{abstract}
Biomass gasification-catalytic liquid fuel (Biomass-to-Liquid: BTL) synthesis is one of promising processes. BTL is advocated to be widely introduced in near future (by 2030) by Japanese government. BTL synthesis is now $R \& D$ stage in Japan and its development is urgently required. We have been studying the gasification of biomass using an entrained-flow type gasifier and clarifying the suitable conditions for synthesizing liquid fuels in the joint researches with companies and universities organized by the New Energy and Industrial Technology Development Organization (NEDO) biomass projects, those are, methanol synthesis in a 2 ton/day scale test plant, bio-LPG synthesis and bio-jet fuel synthesis. We introduce and overview woody and herbaceous biomass gasification and BTL synthesis using an entrained-flow gasifier in Japan.
\end{abstract}

\section{Key Words}

Biomass gasification, Entrained-flow gasifier, BTL, Bio methanol, Bio jet fuel

バイオマスガス化 - 触媒液化による液体燃料合成 (Biomass-to-liquid: BTL) は, 有望なプロセスである。日本政府も 2030 年ま でにBTL を広〈導入することを提唱しており，その早急な開発 - 実用化が迫られている。我々は，噴流床型ガス化炉を用いたバイオ マスのガス化の研究を行っており，後段の触媒合成 - 液体燃料製造に適したガス化の開発を企業や大学と共同で NEDO (新エネ ルギー産業技術開発機構) プロジェクト (2t/d 規模のテストプラントによるガス化 - メタール製造, バイオ LPG 合成, バイオジエット 燃料製造）の中で行ってきた。本稿では，これまで行ってきた噴流床ガス化炉を用いた木質系 - 草本系ガス化と BTL 製造につい て紹介する。

キーワード

バイオマスガス化，噴流床型ガス化炉，BTL, バイオメタノール，バイオジェット燃料

\section{Introduction}

Biomass gasification is a very promising process among biomass-to-energy conversion processes. Biomass gasification is roughly classified into two types from the viewpoint of end use: one is gasification for power generation or cogeneration of heat and power (CHP) and the other is for liquid fuel synthesis (BTL: Biomass-to-Liquid synthesis). Gasification for CHP or power generation, such as small-scale CHP using a fixed-bed type gasifier or largescale co-gasification of coal (mainly) and biomass using a fluidized-bed type or an entrained-flow type gasifier, is gradually but steadily introduced for practical use because high calorific and combustible gas is enough and because no control of gaseous components is required. On the contrary,

Research Institute of Energy Frontier,

National Institute of Advanced Industrial Science and Technology 16-1, Onogawa, Tsukuba-shi, Ibaraki 305-8569, Japan gasification-catalytic liquefaction for liquid fuel synthesis requires severe and precious controls of both gaseous components and gas purification. For this purpose, fluidizedbed type and entrained-flow type gasifers are suitable and developed, as discussed in IEA bioenergy, Task 33 (thermal

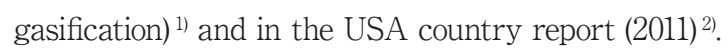

BTL fuels synthesized catalytically from gasified biomass are now at R\&D or demonstration stage in Japan. Based on the roadmap for the Cool-Earth-Innovative Energy Technology Progress (March, 2008) ${ }^{3)}$ and the Basic Energy Plan (June, 2014) ${ }^{4)}$ announced by the Ministry of Economy, Trade and Industry (METI), commercial use of the catalytic synthesized bio liquid fuel by 2030 have been targeted. Because the BTL and microalgae-derived biofuel are promising candidates and their developments are urgently required, New Energy and Industrial Technology 
Development Organization (NEDO) is conducting "Strategic Development of Next-generation Bioenergy Utilization Technology" program, in which production and synthesis of BTL and microalgae-derived fuels are developed ${ }^{5}$.

We have been studying the biomass gasification using an entrained-flow type gasifier and clarifying the suitable conditions for synthesizing liquid fuels and cooperating with companies and/or universities in the NEDO biomass projects ${ }^{6)}{ }^{14}$. Here, we introduce our research results on biomass gasification (using entrained-flow gasifier) for the BTL synthesis.

\section{Gasification using entrained-flow gasifier: concept and basic study}

Many types of gasifiers for biomass have been developed, however, for advanced purposes, such as catalytic chemical synthesis and fuel cell, a fluidized-bed gasifier with a tar reformer and an entrained-flow type gasifier are suitable, as reported in the USA country report by Dr. Bain, the Task Leader of the IEA bioenergy agreement, task $33^{2}$. Center of Fig.1 shows a reactor of the entrained-flow gasifier. It is vacant, to around middle of which feedstock biomass is fed, from bottom of which gasification agent is supplied, and top of which produced gas is obtained. The entrained-flow gasifier has the following advantages: its structure is simple, the tar yield is quite low even without a catalyst or a tar reformer, the gas compositions are easy to be adjusted suitable for liquid fuel synthesis, and it is widely available for many species of whole biomass including unused wastes.

We designed and built a small (laboratory)-scale entrained-flow type gasifier in our laboratory ${ }^{15)}$. Fig. 1 shows a schematic of the gasifier and related equipments.
Woody and herbaceous biomass is pulverized to pieces of 1-2 $\mathrm{mm}$ diameter, and gasified in the presence of gasification agent (usually steam alone or a mixture of steam and oxygen) in the gasifier. Steam is supplied to accelerate gasification and other reactions (hydrolysis, shift-reaction) and oxygen is to partially oxidize biomass and to generate heat. In a large (commercial / demonstration) scale, heat for gasification is supplied by partial oxidation of feedstock biomass alone, however, this gasifier's scale is too small to generate heat for gasification, so an electric furnace is used. Gaseous components obtained are easily and preciously controllable by adjusting supplying rates of steam, oxygen and feedstock biomass, among which molecular ratio of hydrogen and carbon monoxide, $\left[\mathrm{H}_{2}\right] /[\mathrm{CO}]$, is especially important for liquid fuel synthesis.

Various kinds of biomass were gasified using the gasifier. Fig. 2 shows one example of gasification results of seven species of biomass. Although in all feedstock, gasification proceeded well, properties of gasification were dependant on gasification conditions and properties of feedstock biomass. For example, in the case of Japanese cedar wood, gasification rate (carbon conversion into gas) was $97 \%$ and $\left[\mathrm{H}_{2} \mathrm{O}\right] /[\mathrm{CO}]=2.6$, suitable gas for liquid fuel synthesis was obtained. At requests of organizations (universities and institutes), we provide these gas to them, and using these gas FT-oil and other BTL were synthesized.

\section{Biomass gasification-Liquid fuel (methanol) synthesis (NEDO biomass project)}

Mitsubishi Heavy Industries Ltd. (MHI) had first studied biomass gasification by using a bench-scale entrained-flow gasifier in a MAFF project, in which an

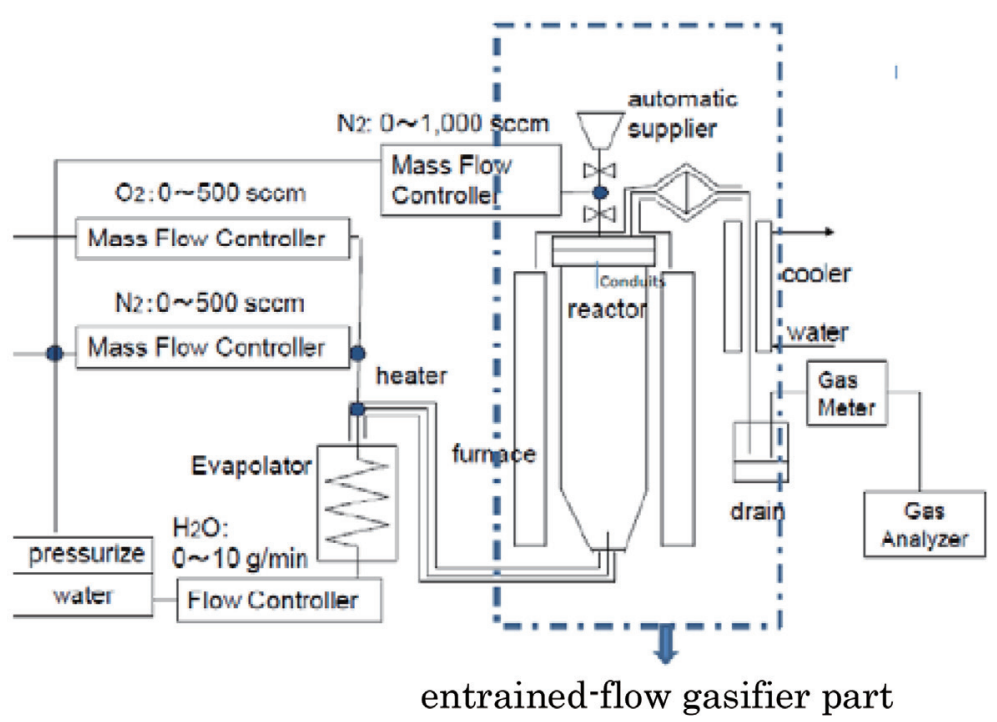

Fig. 1 Schematic of an entrained-flow gasifier 


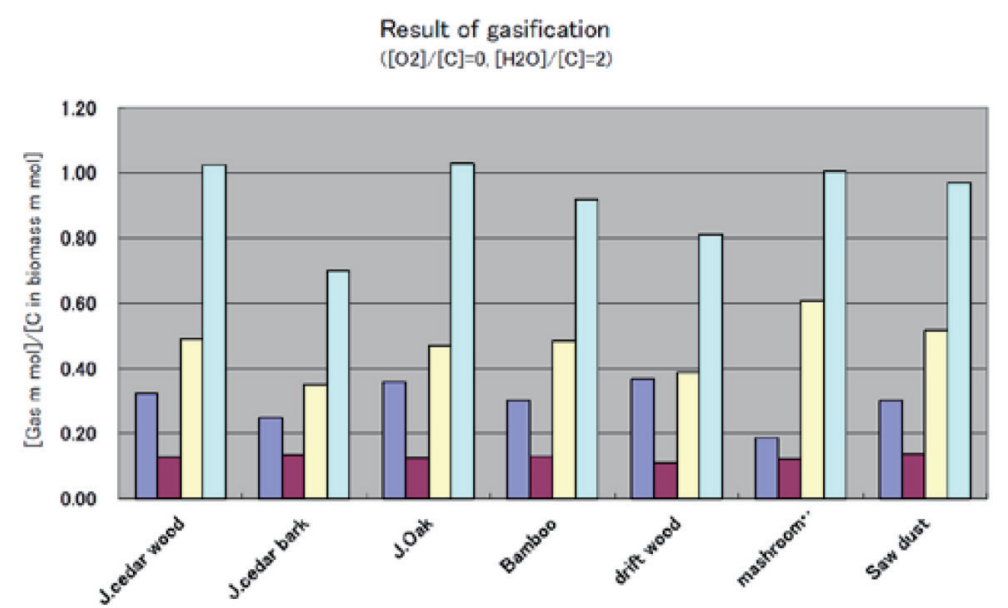

Fig. 2 Result of gasification

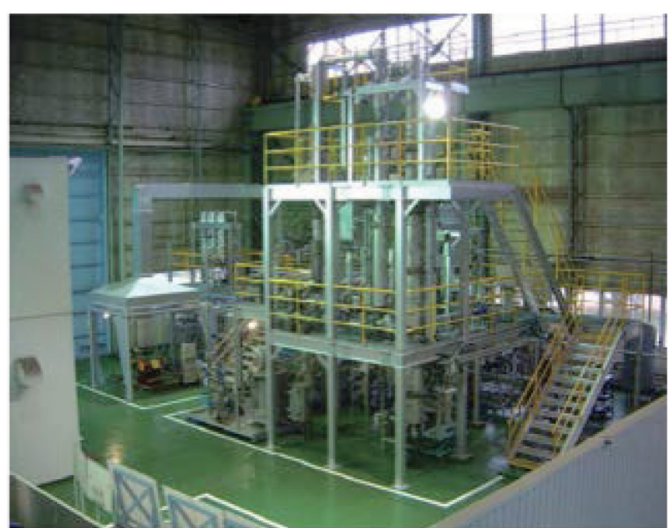

Fig. 3 Bench-scale entrained-flow biomass gasifier (at MHI Nagasaki Laboratory)

electric furnace was used to heat the gasifier (Fig. 3) ${ }^{16}$. Liquid fuel (methanol) was synthesized from the gas obtained through a purifier filled with activated carbon and a synthesis reactor packed with a $\mathrm{Cu} / \mathrm{Zn}$ type catalyst.

Based on the fundamental research and experience, MHI, Chubu Electric Power Corporation (CEPCO) and our group in AIST developed a 2 ton/day-scale test plant for studying the overall process of woody biomass gasification and liquid fuel (methanol) synthesis in the Biomass Project sponsored by NEDO ${ }^{17) \sim 19)}$. Figs. 4 and 5 respectively show the total scheme of the gasification-methanol synthesis process and overview of the test plant built in the CEPCO's Kawagoe power generation area. The test plant was the first successful study of a complete system of biomass preparation, gasification and methanol synthesis with a selfheating gasifier, in which feedstock biomass was partially oxidized to generate heat that kept the temperature high enough for gasification without external heating. Six kinds of biomass and biomass wastes, including driftwood, Japanese cedar wood and bark, were tested. The energy conversion ratio of the feedstock biomass to the gas obtained (cold gas efficiency) was higher than $60 \%$ and more than $200 \mathrm{~kg}$ of methanol was synthesized from a air dried biomass of 1 ton, which corresponded to an energy conversion ratio greater than $75 \%$ and methanol synthesis yield higher than $40 \mathrm{wt} \%$ in a commercial scale plant with heat loss less than

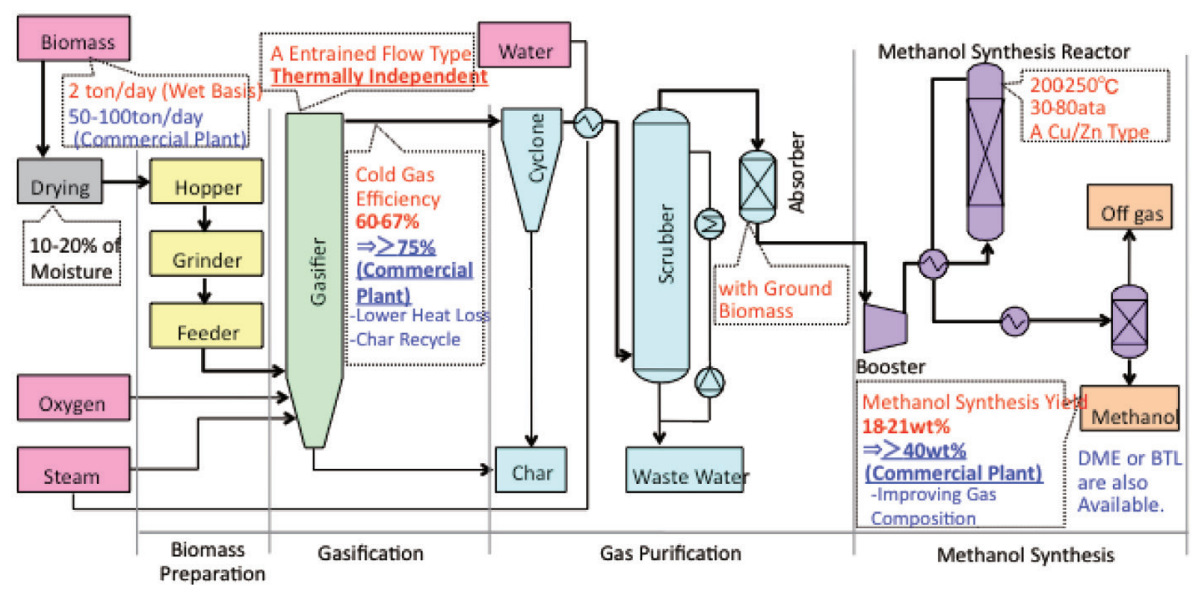

Fig. 4 A schematic diagram and test results of a biomass gasification methanol synthesis system ${ }^{18}$ 


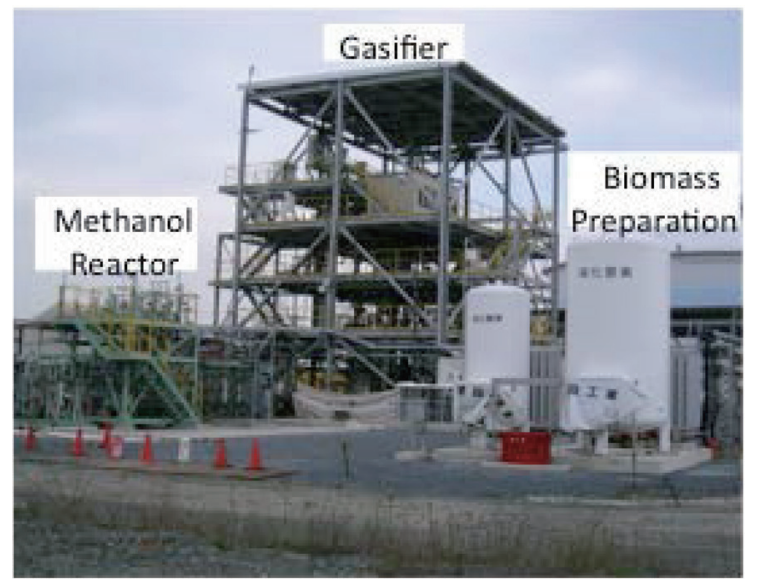

Fig. 5 Overview of the 2 ton/day-scale test plant in CEPCO Kawagoe ${ }^{18)}$

$1 \%$. Methanol synthesized from biomass is a renewable liquid bio fuel, which can be stored and utilized as fuel for engine, turbine, and fuel cell, and chemical source for fatty acid methyl ester (FAME or BDF) and $\mathrm{Cl}$ chemistry.

Based on the test runs and results, a char recycling and tar absorbing equipments were developed in further research of another NEDO project ${ }^{20)}$. When operated with them, performances, such as gasification rate and energy conversion rate, would be improved about $5 \%$.

\section{Biomass gasification-bio LPG synthesis (NEDO project)}

In the NEDO Next-generation program, Japan Gas Synthesis Co. Ltd., the University of Kitakyushu and our group in AIST challenged to establish bio-LPG synthesis process using the gas obtained from biomass and a hybrid LPG catalyst ${ }^{21)}$ 22).

In Japan, municipal gas with pipeline systems is available in limited areas of large population, and the rest of area of more than $90 \%$ liquefied petroleum gas (LPG) is supplied. LPG of about 15-16 Mt is consumed in every year (about 750-800 PJ/year). "Energy Kyokyu Koudoka Hou (Act of Sophisticated Methods of Energy Supply Structures)," established in 2010, advocates LPG suppliers are mandated to introduce bio-gas ${ }^{23)}$. Synthesized LPG from biomassderived syngas, bio-LPG, is expected as one of the most promising candidates.

Fig. 6 shows a concept of the bio-LPG process and the present LPG-supply chain in Japan.

Bio-LPG process consists of entrained-flow type biomass gasification technology and direct LPG synthesis process. Properties of the biomass-derived syngas (obtained by using the laboratory-scale gasifier and reactors at our laboratory, which were described in section 2) and the LPG synthesis were studied. Based on them, performances of a

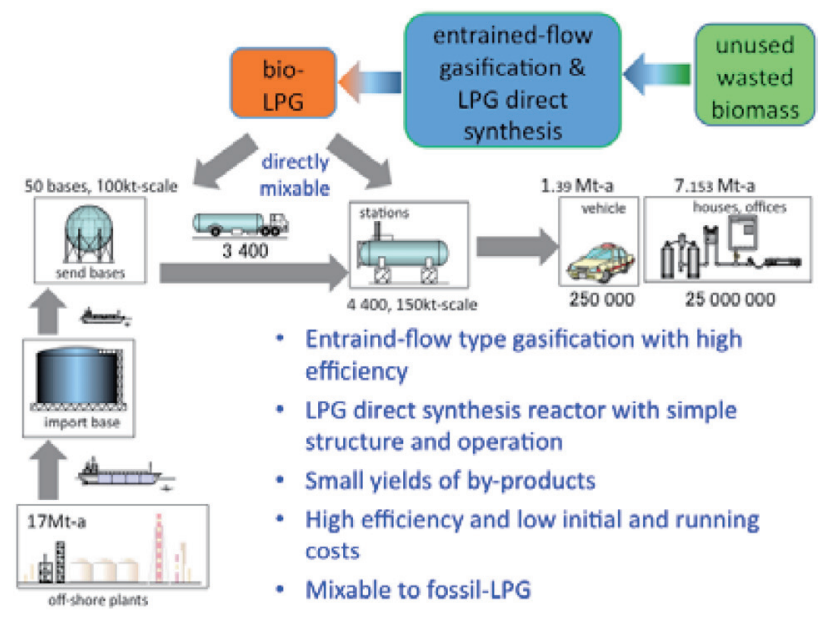

Fig. 6 Concept of bio-LPG process and LPG-supply chain in Japan

commercial-scale bio-LPG plant were estimated, 100 t/dayscale of which was determined as considering reports from Mitsubishi Heavy Industries, Ltd. ${ }^{17) \sim 20}$.

The plant simulation indicated that total performances of a commercial-scale bio-LPG plant were depended on effective uses of heat exchanged from hot synthesized gas (syngas) and by-produced from the LPG synthesis reactor, and on properly controlled components of syngas suitable for LPG synthesis. The bio-LPG process has many advantages, such as (1) high energy conversion rate from feedstock biomass to syngas, cold gas efficiency, of $75 \%$ or more, (2) simple structure and operation of direct LPG synthesis reactor, (3) small yields of by-products, such as solid residues and tar, (4) low initial and running costs and (5) directly mixable to fossil LPG with no limitations.

\section{Biomass gasification-bio jet fuel synthesis (NEDO project) \\ "The next generation jet fuel initiative" was} organized in 2014, and works for establishing road map of supply chain of bio jet fuel by 2020 have started ${ }^{24}$. MHI, Toyama University, JX Nippon Oil \& Energy Corporation, Clariant Catalysis K.K and our group in AIST have been trying to develop an innovative bio jet fuel production system from biomass (bio-jet fuel) in the NEDO Nextgeneration program.

Fig. 7 shows the scheme of the bio-jet fuel process. This project focuses on the development of innovative entrained-flow gasifier suitable for Fischer-Tropsch (FT) synthesis with high selectivity and durability, to which feedstock of larger size is applicable. Because not only development of stand-alone process but also a total system solution are required to commercialize the BTL technology, this project targets to study a total integrated system 


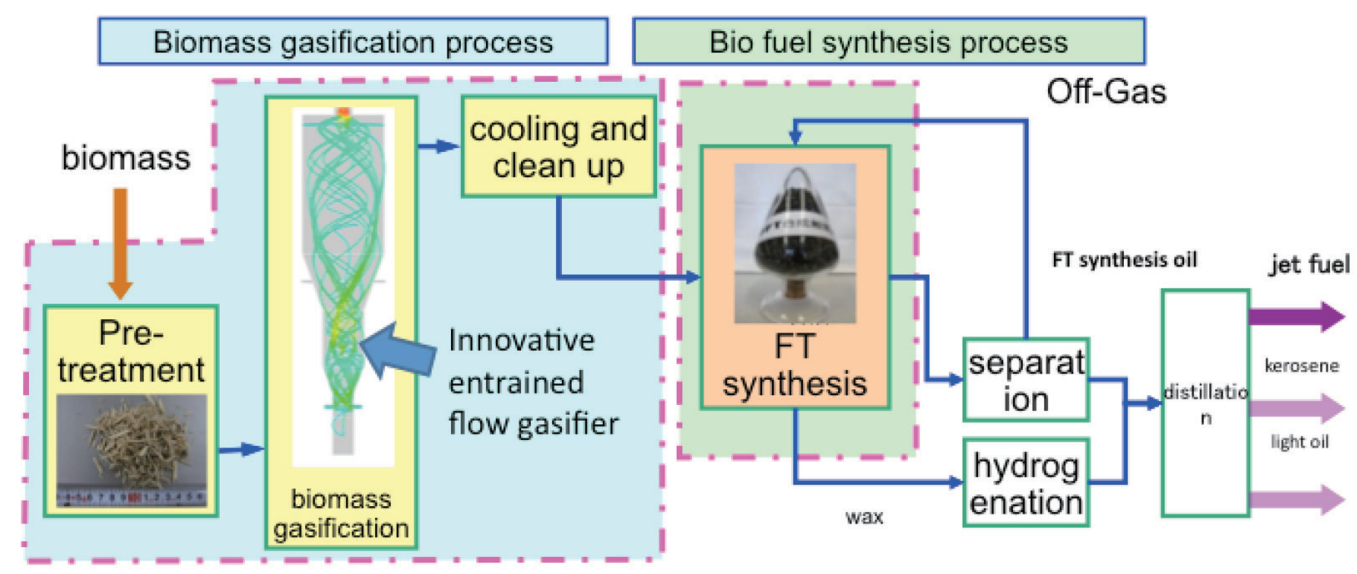

Fig. 7 A scheme of biomass gasification and bio-jet fuel (FT) synthesis system

including biomass pretreatment, feeding, gasification, purification, precious control of gaseous compositions and FT-synthesis.

\section{Conclusion--In the future}

An integrated system of biomass gasification liquid fuel synthesis is quite promising and has been developed in a small test plant stage. To commercialize the BTL system, demonstration in a larger scale to verify higher efficiency and lower cost is required.

\section{Acknowledgment}

These studies were funded by NEDO. Authors thank to Dr. M. Hishida, Dr. K. Shinoda, Dr. T. Amari, Dr. T. Yamamoto, Dr. K. Matsumoto, Mitsubishi Heavy Industries Ltd., and Prof. K. Takeno, Toyota Technological Institute, for their kind discussions on entrained-flow type biomass gasification. Authors thank to Prof. Fujimoto, The University of Kitakyushu, for his discussion on bio-LPG catalyst and synthesis.

\section{References}

1) IEA Bioenergy Agreement task33, http://www. ieatask33.org/ (Last access: 2014.11.6)

2) IEA Bioenergy Agreement task33, country report the U.S.A., http://www.ieatask33.org/ app/webroot/files/ file/country_reports/USA.pdf (Last access: 2014.11.6)

3) Ministry of Economy, Trade, and Industry, http:// www.enecho.meti.go.jp/category/others/for_energy_ technology/001.html (Last access: 2014.11.6)

4) Ministry of Economy, Trade, and Industry, http:// www.enecho.meti.go.jp/category/others/basic_plan/ pdf/140411.pdf (Last access: 2014.11.6)

5) New Energy and Industrial Technology Development Organization, http://www.nedo.go.jp/activities/ CA_004551.html (Last access: 2014.11.6)
6) Ogi, T.; Nakanishi, M.; Inoue, S., Proceedings of the 8th Japan-China symposium on coal and C1 chemistry, 1, 227-228 (2003)

7) Ogi, T.; Nakanishi, M.; Inoue, S., Science in thermal and chemical biomass conversion, 1, 620-630 (2005)

8) Ogi, T.; Kawamura, A.; Nakanishi, M.; Inoue, S., Proceedings of IAWPS2005, 2, 257-258 (2005)

9) Ogi, T.; Nakanishi, M., Renewable Energy, 1, 1050-1054 (2006)

10) Matsumoto, K.; Takeno, K.; Ichinose, T.; Ogi, T.; Nakanishi, M., Fuel, 88, 519-527 (2009)

11) Matsumoto, K.; Takeno, K.; Ichiose, T.; Ogi, T.; Nakanishi, M., Energy \& Fuel, 24, 1980-1986 (2010)

12) Ogi, T.; Nakanishi, M.; Fukuda, Y., Renewable Energy, 1, 094701-1-3 (2010)

13) Ogi, T.; Nakanishi, M.; Fukuda, Y., J. Jpn. Inst. Energy, 90, 886-894 (2011)

14) Ogi, T:; Nakanishi, M.; Fukuda, Y., Matsumoto, K: Fuel, 104, 28-35 (2013)

15) Nakanishi, M.; Ogi, T., Kankyo gijyutu (Environ Conver Energy), 34, 522-527 (2005)

16) Nakagawa, H.; Sakai, M.; Harada, T.; Ichinose, T.; Takeno, K.; Matsumoto, S.: Kobayasi, M.; Matsumoto, K.; Yakushido, K., Biofuel' s Engineering Process Technology, (2011), http://www.intechopen.com/books/ biofuel-s-engineering-process-technology (Last access: 2014.11.6)

17) Nakatani, H.; Ishii, H.; Fukui, K.; Nishimura, K.; Takeno, K.; Matsumoto, K., MHI Technical Review, 42, 130-133 (2005)

18) Matsumoto, K.; Takeno, K.; Ichinose, T.; Ishii, H.; Nishimura, K., Proceedings of the 15th Euro biomass conference and exhibition, 1945-1950 (2007)

19) Mori, R.; Oki, Y.; Takeno, K.; Matsumoto, K.; Kobayasi, Y.; Ishii, H., MHI Technical Review, 45, 62-64 (2008)

20) Matsumoto, K.; Takeno, K,; Ichinose, T.; Nakanishi, M.; 
Ogi, T., 16th Euro biomass conference and exhibition, 877-882 (2008)

21) Ogi, T.; Nakanishi, M.; Fujimoto, K., Proceedings of IEA Bioenergy Conference 2012, (2012), http://www. ieabioenergy2012.org/contributions.html (Last access: 2014.11.6)

22) Fujimoto, K.; Congming, L.; Xingdong, Y.; Muroi, T.; Yoshino, K., Proceedings of 9th Biomass Asian Workshop, (2012), http://www.biomass-asia-workshop.
jp/biomassws/09workshop/jp/Program_I.htm (Last access: 2014.11.6)

23) Ministry of Economy, Trade, and Industry, http:// www.enecho.meti.go.jp/notice/topics/017/ (Last access: 2014.11.6)

24) Center for Aviation Innovation Research, The University of Tokyo, http://aviation.u-tokyo.ac.jp/ eventfile/20140731Teigen01.pdf (Last access: 2014.11.6) 